Marquette University

e-Publications@Marquette

Chemistry Faculty Research and Publications

Chemistry, Department of

9-15-2005

\title{
Electrochemical Attachment of Motile Bacterial Cells to Gold
}

Sergey Rozhok

Northwestern University

Richard C. Holz

Marquette University, richard.holz@marquette.edu

Accepted version. Talanta, Vol. 67, No. 3 (September 15, 2005): 538-542. DOI. (C) 2005 Elsevier B.V. Used with permission.

Richard Holz was affiliated with the Utah State University at the time of publication. 


\section{Marquette University}

\section{e-Publications@Marquette}

\section{Chemistry Faculty Research and Publications/College of Arts and Sciences}

This paper is NOT THE PUBLISHED VERSION; but the author's final, peer-reviewed manuscript. The published version may be accessed by following the link in the citation below.

Talanta, Vol. 67, No. 3 (September 2005): 538-542. DOI. This article is (C) Elsevier and permission has been granted for this version to appear in e-Publications@Marquette. Elsevier does not grant permission for this article to be further copied/distributed or hosted elsewhere without the express permission from Elsevier.

\section{Electrochemical attachment of motile bacterial cells to gold}

\section{Sergey Rozhok}

Department of Chemistry and Biochemistry, Utah State University, Logan, UT

Department of Chemistry and Institute for Nanotechnology, Northwestern University, 2145 Sheridan, Rd.

Evanston, IL

\section{Richard Holz}

Department of Chemistry, Marquette University, Milwaukee WI

Department of Chemistry and Biochemistry, Utah State University, Logan, UT 84322-0300, USA

\section{Abstract}

Selective attachment of Escherichia coli K-12 bacterial cells to charged gold surfaces was demonstrated. Electrostatic binding of $E$. coli $\mathrm{K}-12$ bacterial cells to positively charged surfaces was observed starting at $+750 \mathrm{mV}$. The binding of $E$. coli $\mathrm{K}-12$ cells to positively charged gold surfaces is proposed to occur due to longrange electrostatic interactions between the negatively charged O-chain of lipopolysaccharide (LPS) molecules protruding the bacterial cell body and the electrode surface. Removing LPS alters the cellular surface charge and results in cellular attachment to negatively charged surfaces. Thus, applying an electrical potential allows for the direct, real time detection of live, dead or damaged bacterial cells. The attachment of $E$. coli $\mathrm{K}-12$ bacterial cells to surfaces with an applied potential substantiates the hypothesis that an electrostatic interaction is responsible for the binding of bacterial cells to positively charged molecular assemblies on surfaces used for building bacterial microarrays. 


\section{Keywords}

E. coli K-12, Cell attachment, Bacterial binding

\section{Introduction}

A great deal of effort has gone into the development of modified surfaces that resist cellular adhesion [1], [2], [3], [4], [5], and such surfaces have been used in sensor development [2], [6], and biomaterials [2], [7], [8], [9]. Previous approaches to attach whole, motile bacterial cells to surfaces centered around the random attachment of bacteria through their flagella as well as fimbriae and pilli [10], [11], [12]. However, motile bacterial cells can adhere to surfaces through cell surface macromolecules via both specific and non-specific interactions involving hydrophobic, hydrophilic and/or van der Waal forces [1], [13], [14]. It has previously been shown that motile Escherichia coli cells could be randomly adhered to a surface through interactions with an antibody[15], [16], and similar results have been obtained for motile bacterial cells, such as Salmonella typhimurium and Helicobacter pylori [14], [17], [18], [19]. In addition, whole bacterial cells have been shown to randomly adhere to surfaces coated with polysaccharides, polystyrene, poly-I-lysine, and even hyper-branched polymer film templates [1], [4], [6], [13], [20], [21], [22].

Recently, microarrays of motile bacterial cells were prepared by attaching $E$. coli K-12 cells to pre-designed micron-sized patterns of 16-mercaptohexadecanoic acid (MHA) patterned on gold surface via microcontact printing and treated with poly-I-lysine (PLL) [23]. Based on these data, a single motile E. coli bacterial cell can be attached to a pre-designed line or dot feature with binding occurring primarily via the cell body, however, some surface-flagella binding also occurred. In addition, surface bound bacteria were shown to remain alive and motile after adhesion to a patterned surface for more than $4 \mathrm{~h}$ [23]. The observed binding of $E$. coli $\mathrm{K}-12$ bacterial cells to MHA-PLL surface patterns at $\mathrm{pH} 7.8$, was proposed to be due to electrostatic interactions between the negatively charged $E$. coli cells [24] and the protonated amino groups $\left(\mathrm{NH}_{3}{ }^{+}\right)$of poly-I-lysine.

In order to understand in greater detail the binding mechanism of E. coli K-12 motile bacterial cells to surfaces, we have examined the effect of electrochemical potential applied to a bare gold surface on $E$. coli binding. Our data indicate that negatively charged gold surfaces repel $E$. coli K-12 motile bacterial cells while positively charged surfaces bind $E$. coli cells. In addition, the electrostatic interaction between $E$. coli $\mathrm{K}-12$ motile bacterial cells and charged surfaces was examined by altering the surface charge of $E$. coli K-12 bacterial cells. These data verify the hypothesis that bacterial binding to microarrays is due to electrostatic forces.

\section{Materials and methods}

\subsection{Materials}

The tetrasodium salt of ethylenediaminetetraacetate (EDTA) was purchased from Aldrich/Sigma Chemical Co. (Milwaukee, WI) and used as received without further purification. Milli-Q water (18.2 M $\Omega$ ) was used for all aqueous experiments. Gram-rods of $E$. coli K12 bacterial cells were purchased from the Carolina Biological Supply Company.

\subsection{Bacterial cell preparation}

E. coli K-12 bacterial cells were grown from a single colony in Luria-Bertani (LB) broth in a rotary shaker incubator at $37{ }^{\circ} \mathrm{C}$ and $225 \mathrm{rpm}$ for $7-8 \mathrm{~h}$. When the optical density $\left(\mathrm{OD}_{600}\right)$ of the culture reached ca. $0.8-1.0$ (Agilent 8453 UV-vis spectroscopy system), the bacterial cells were centrifuged at $4000 \mathrm{rpm}$ for $20 \mathrm{~min}$ and resuspended in M9 media prepared from commercially available M9 minimal salts. The final bacterial concentration was approximately $(1-2) \times 10^{7}$ cells $/ \mathrm{mL}$, which was determined by measuring the absorbance at $600 \mathrm{~nm}$ and by counting cells methods using a Bright-Line hemacytometer (Fisher Scientific). 


\subsection{Imaging}

Fabricated microarrays were characterized by optical and atomic force microscopy's (AFM). Either a Veeco CPResearch or Nanoscope IV (Nanoman) was employed to acquire topography and frictional force images. The cantilever tip (Model \# MSCT-AUHW, purchased from Veeco) had a spring constant of $0.05 \mathrm{~N} / \mathrm{m}$. Optical images were obtained with an Axiovert 100A optical microscope equipped with a Penguin $600 \mathrm{CL}$ digital camera and StreamPix software.

\section{Results and discussion}

Recently, it was proposed that $E$. coli K-12 bacterial cells bind to MHA-PLL modified gold surfaces through an electrostatic interaction between the protonated amino groups $\left(\mathrm{NH}_{3}{ }^{+}\right)$of poly-l-lysine and the negatively charged surface of $E$. coli cells [23]. In order to test this hypothesis, we have examined the effect of electrochemical potential on E. coli K-12 bacterial cell adhesion to bare gold surfaces. The attachment $E$. coli K12 bacterial cells to bare gold surfaces were performed under ambient conditions using a Bass 100 electrochemical apparatus (Scheme 1). Briefly, a voltage was applied between a gold substrate (working electrode) and a platinum counter electrode and measured with respect to a silver/silver-chloride reference electrode. E. coli K-12 bacterial cells were grown as previously described [23] and transferred to M9 media at $37^{\circ} \mathrm{C}$. Approximately $25 \mathrm{ml}$ of $\mathrm{M} 9$ media containing $E$. coli $\mathrm{K}-12$ bacterial cells $(\mathrm{OD}=1)$ was used for each electrochemical attachment experiment. In order to exclude unspecific binding, the gold substrate was immersed and removed from cell containing M9 media under the voltage conditions indicated for each experiment. Electrochemical attachment of $E$. coli K-12 bacterial cells was initially examined at potentials of $V=0$ and $\pm 1000 \mathrm{mV}$ applied to a gold substrate for $\sim 5 \mathrm{~min}$. After each experiment, the substrate was removed from the M9 media, washed in nanopure water, and dried in air and optical and AFM studies were conducted.

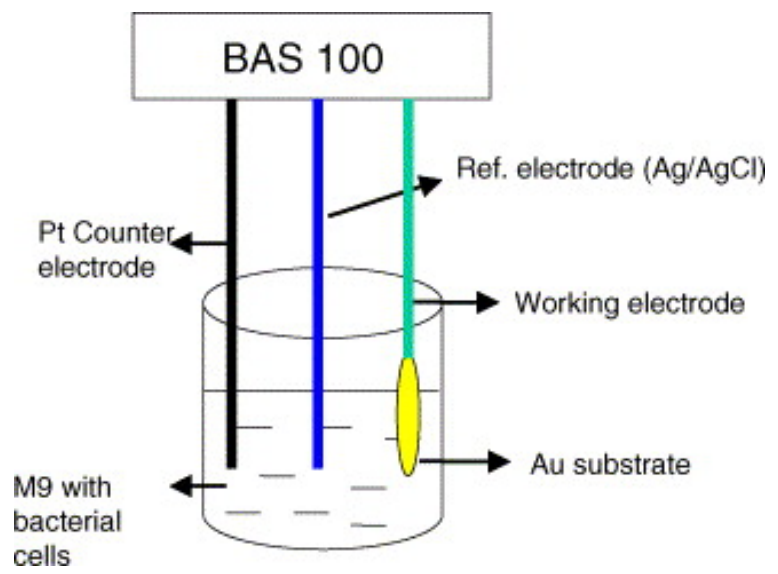

Scheme 1. Sketch of the experimental setup used for the electrochemical binding studies described herein for $E$. coli K-12 bacterial cells to gold substrates.

Optical images of $E$. coli $\mathrm{K}-12$ bacterial cells bound to bare gold surfaces at $+1000,0$ and $-1000 \mathrm{mV}$ indicate that negatively charged surfaces repel $E$. coli K-12 cells while positively charged surfaces attract them and cause cellsurface attachment (Fig. 1 ). These data are consistent with the proposal that $E$. coli cell surfaces are negatively charged due to surface phosphate and carboxylate groups composing the core region of lipopollysaccharide (LPS) molecules [24]. Applying a negative potential $(-1000 \mathrm{mV})$ to electrochemically attached $E$. coli $\mathrm{K}-12$ cells removes $\sim 60 \%$ of the bacteria from the gold electrode surface. These data indicate that the electrochemical attachment process is only partially reversible. Based on atomic force microscopy (AFM), E. coli K-12 cells attached to gold surfaces at $+1000,0$ or $-1000 \mathrm{mV}$ are significantly different in both shape and cell surface integrity. E. coli K-12 cells attached to positively charged $(+1000 \mathrm{mV})$ and neutral gold surfaces are in good condition and exhibit the shape and cell surface features expected for a healthy bacterial cell (igig. $2 A$ and B). In 
contrast, E. coli $\mathrm{K}-12$ cells attached to negatively charged $(-1000 \mathrm{mV})$ bare gold surfaces experience cell wall destruction and exhibit fractured flagella that are not protruding from the bacterial cell bodies (Fig. $2 \mathrm{C}$ ). Flagella binding to a negatively charged surface, indicates that bacterial flagella are positively charged. Archaeal flagellins composing the flagellum filament have positively charged amino acids [25], likely resulting in the electrostatic attraction to negative surfaces.

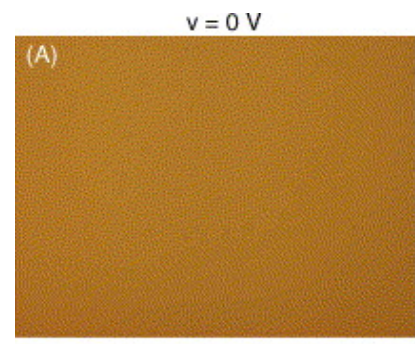

$\mu \mathrm{m}$

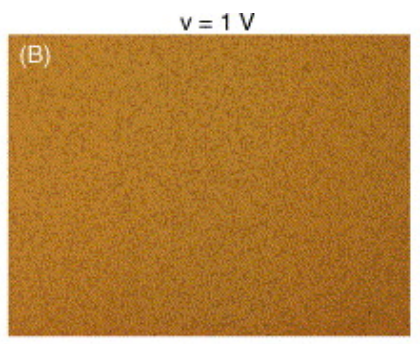

$\mu \mathrm{m}$

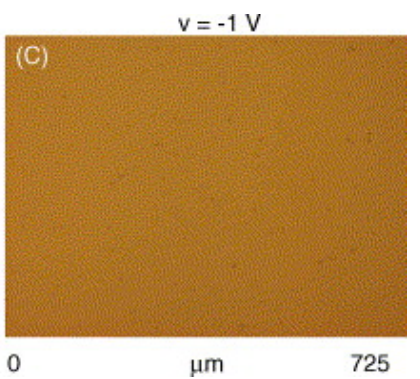

Fig. 1. Optical images of $E$. coli $\mathrm{K}-12$ bacterial cells attached to: (A) neutral, (B) positively and (C) negatively charged bare gold substrates.

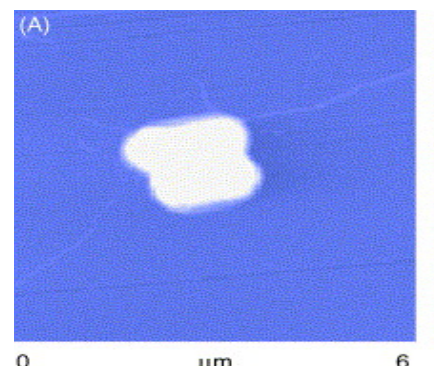

$\mu \mathrm{m}$

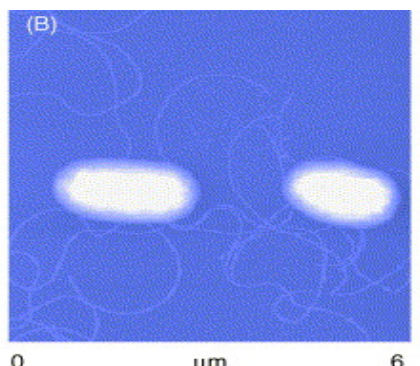

$\mu \mathrm{m}$

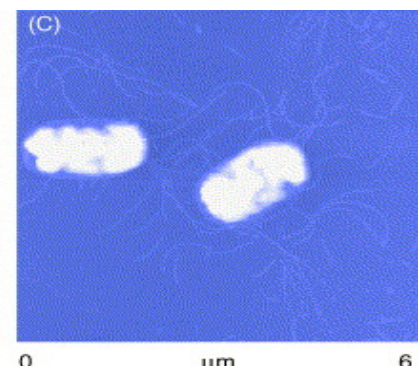

$\mu \mathrm{m}$

Fig. 2. AFM images of $E$. coli $\mathrm{K}-12$ bacterial cells bound to: (A) neutral, (B) positively, and (C) negatively charged bare gold substrates.

In order to determine the minimum electrochemical potential needed to attached $E$. coli $\mathrm{K}-12$ bacterial cells to gold surfaces, voltages ranging from $V= \pm 250, \pm 500$ and $\pm 750 \mathrm{mV}$ were examined. Optical images of $E$. coli $\mathrm{K}-12$ bound to bare gold surfaces at $\pm 250, \pm 500$ and $\pm 750 \mathrm{mV}$ indicate that $E$. coli cells will bind to bare gold surfaces only at potentials $\geq+750 \mathrm{mV}(\underline{\text { Fig. } 3})$. These data indicate that $E$. coli $\mathrm{K}-12$ bacterial cells can be attached to surfaces through electrostatic forces and that the cell surface is negatively charged. While the majority of cells bind to positively charged gold surfaces, some bacteria attach to negatively charged surfaces indicative of some positive charge build-up on cellular surfaces. Positively charged $E$. coli cell surfaces are likely due to the destruction of negative O-chains of LPS molecules that shield a positively charged core region [24], [26]. The observed perturbations in the shape of the cell surface of bacteria attached to positively charged surfaces (Fig. $\underline{2}$ ) ) are likely the result of LPS damage. 

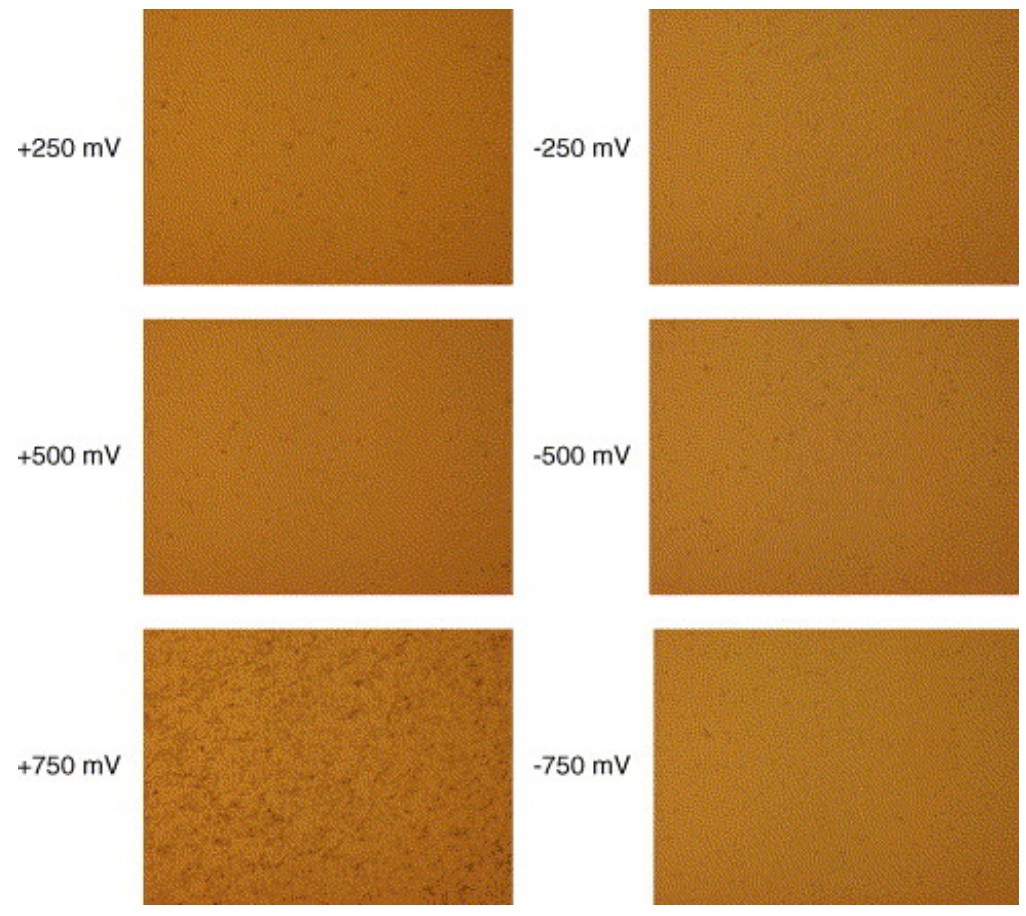

Fig. 3. E. coli K-12 bacterial cell attachment to bare gold surface at $\pm 250, \pm 500$ and $\pm 750 \mathrm{mV}$.

Examination of the role of LPS in forming negative charge of the cell envelope and the electrostatic interaction between $E$. coli K-12 bacterial cells and positively charged surfaces was further probed by altering the charge on the cellular surface by treating bacterial cells with ethylenediaminetetraacetate (EDTA). The addition of EDTA disrupts the LPS molecular assembly resulting in removal of O-antigen giving a positive charge to the cell surface [27]. After bacteria were grown in LB media they were centrifuged and washed in nanopure water, recentrifuged and resuspended in a $10 \mathrm{mM}$ aqueous solution of EDTA for $30 \mathrm{~min}$ after which they were centrifuged and resuspended in M9 media and allowed to stand for $\sim 40 \mathrm{~min}$ at $37^{\circ} \mathrm{C}$. A voltage was applied to a gold substrate, immersed in M9 media containing E. coli K-12 cells treated with EDTA, for 5 min at a potential of $V=-1000 \mathrm{mV}$. The substrate was removed from the M9 media, washed in nanopure water, dried in air and optical and AFM studies were recorded.

Optical images of $E$. coli K-12 bacterial cells bound to a bare gold surface with an applied potential of $-1000 \mathrm{mV}$ before and after treatment with EDTA are shown in Fig. 4. Interestingly, EDTA treated E. coli K-12 cells are now attracted to the negatively charged surface, exactly opposite to what is observed with untreated $E$. coli $\mathrm{K}-12$ cells. A positive charge build-up on the surface of $E$. coli K-12 cells likely occurs due to the degradation of the Ochains of LPS molecules, which shield a positively charged core region [24], [26]. High-resolution AFM images of E. coli K-12 cells before and after treatment with EDTA (Fig. 5A and B) reveal the difference in the shape and size of the bacterial cells. The AFM image of an un-treated E. coli K-12 cell indicates the presence of flagella and pili around a well-shaped cell body (Fig. 5A). Conversely, an AFM image of an E. coli K-12 cell treated with EDTA does not show any flagella or pili present, but indicates that disruptions in the bacterial cell envelope occur (Fig. 5B). These data suggest that treatment of $E$. coli K-12 cells with EDTA causes damage to the LPS chains on the surface of the cell body resulting in a positively charged cell surface. 

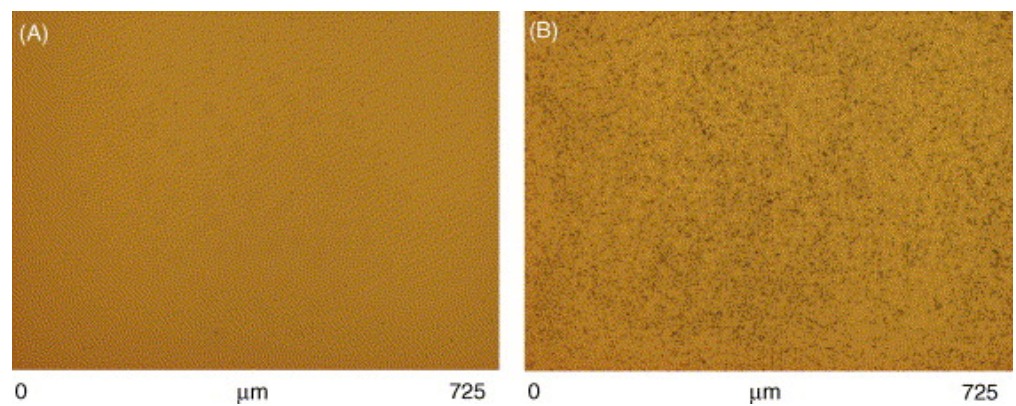

Fig. 4. E. coli K-12 bacterial cell attachment to negatively charged gold surfaces: (A) before and (B) after treatment with $10 \mathrm{mM}$ EDTA.
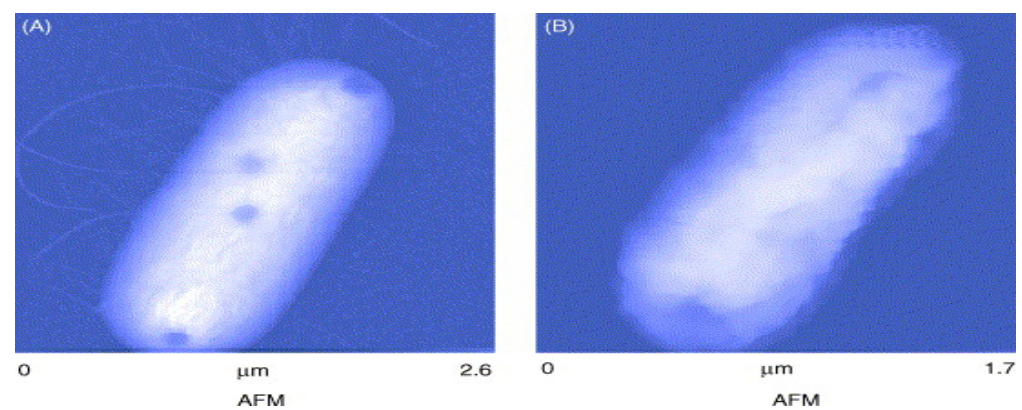

Fig. 5. High-resolution AFM images of E. coli K-12 bacterial cells (A) before and (B) after treatment with EDTA demonstrating the presence of flagella and pili for healthy cells $(A)$ and absence of these features for the cells treated with EDTA (B).

In conclusion, the attachment of $E$. coli $\mathrm{K}-12$ bacterial cell to MHA-PLL surfaces was hypothesized to be due to electrostatic interactions between negatively charged groups on the cell surface of $E$. coli $\mathrm{K}-12$ cells and the positively charged PLL molecule [23]. Based on the data reported herein, E. coli K-12 bacterial cells are only attracted to positively charged surfaces and only when a potential of at least $+750 \mathrm{mV}$ is applied. These data indicate that the cell surface is negatively charged, thus substantiating the proposed binding of $E$. coli $\mathrm{K}-12$ cells to PLL. In addition, treatment of E. coli K-12 cells with EDTA disrupted surface LPS molecules, which resulted in a loss of the negative charge on the cell surface. Therefore, LPS is likely the main negatively charged species on the cell surface and, therefore, accounts for most of the electrostatic interaction with PLL. These data also indicate that applying an electrical potential allows the direct, real time detection of live, dead or damaged bacterial cells.

\section{Acknowledgments}

This work was supported by the Air Force Office of Scientific Research (F49620-02-1-0375 and F49620-03-10382; RCH) and the Defense Advanced Research Projects Agency.

\section{References}

[1] E. Ostuni, R.G. Chapman, M.N. Liang, G. Meluleni, G. Pier, D.E. Ingber, G.M. Whitesides Langmuir, 17 (2001), p. 6336

[2] K.-B. Lee, S.-J. Park, C.A. Mirkin, C.S. Jennifer, M. Mrksich Science, 295 (2002), p. 1702

[3] R.G. Chapman, E. Ostuni, M.N. Liang, G. Meluleni, E. Kim, L. Yan, G. Pier, H. Warren, G.M. Whitesides Langmuir, 17 (2001), p. 1225

[4] E. Ostuni, R.G. Chapman, R.E. Holmlin, S. Takayama, G.M. Whitesides Langmuir, 17 (2001), p. 5605 
[5] A. Razatos, Y.L. Ong, F. Boulay, D.L. Elbert, J.A. Hubbell, M.M. Sharma, G. Georgiou Langmuir, 16 (2000), p. 9155

[6] X.P. Qian, S.J. Metallo, I.S. Choi, H.K. Wu, M.N. Liang, G.M. Whitesides Anal. Chem., 74 (2002), p. 1805

[7] H.D. Inerowicz, S. Howell, F.E. Regnier, R. Reifenberger Langmuir, 18 (2002), p. 5263

[8] J.P. Renault, A. Bernard, A. Bietsch, B. Michel, H.R. Bosshard, E. Delamarche, M. Kreiter, B. Hecht, U.P. Wild J. Phys. Chem. B, 107 (2003), p. 703

[9] D.L. Wilson, R. Martin, S. Hong, M. Cronin-Golomb, C.A. Mirkin, D.L. Kaplin PNAS, 98 (2001), p. 13660

[10] M. Eisenbach, A. Wolf, M. Welch, S.R. Caplin, I.R. Lapidus, R.M. Macnab, H. Aloni, O. Asher J. Mol. Biol., 211 (1990), p. 551

[11] H.C. Berg Philos. Trans. R. Soc. Lond., Ser. B., 355 (2000), p. 491

[12] M.N. Liang, S.P. Smith, S.J. Metallo, I.S. Choi, M. Prentiss, G.M. Whitesides Proc. Natl. Acad. Sci. U.S.A., 97 (2000), p. 13092

[13] J.A. Verschoor, M.J. Meiring, S. Van Wyngraardt, K. Weyer J. Immunoassay, 11 (1990), p. 413

[14] J.R. Premkumar, O. Lev, R.S. Marks, B. Polyak, R. Rosen, S. Belkin Talanta, 55 (2001), p. 1029

[15] R.M.St. John, R. Davis, N. Cady, J. Czajka, C.A. Batt, H.G. Craighead Anal. Chem., 70 (1998), p. 1108

[16] S.W. Howell, H.D. Inerowicz, F.E. Regnier, R. Reifenberger Langmuir, 19 (2003), p. 436

[17] A. Razatos, Y.L. Ong, M.M. Sharma, G.P. Georgiou Proc. Natl. Acad. Sci. U.S.A., 95 (1998), p. 11059

[18] S.E. Seggerson, S.C. Basu American Chemical Society 223rd National Meeting, Orlando, Florida (2002)

[19] C. Czerkinsky, A.S. Rees, L.A. Bergmeier, S.J. Challacombe J. Clin. Exp. Immunol., 53 (1983), p. 192

[20] B. Rowan, M.A. Wheeler, R.M. Crooks Langmuir, 18 (2002), p. 9914

[21] A. Razatos, Y.L. Ong, M.M. Sharma, G.P. Georgiou J. Biomater. Sci.-Polym. Ed., 9 (1998), p. 1361

[22] J.F. Jones, J.D. Feick, D. Imoudu, N. Chukwumah, M. Vigeant, D. Velegol Appl. Environ. Microbiol., 69 (2003), p. 6515

[23] S. Rozhok, C.K.-F. Shen, P.-L.H. Littler, Z. Fan, C. Liu, C.A. Mirkin, R. Holz Small, 1 (4) (2005), p. 445

[24] N.I. Abu-Lail, T.A. Camesano Environ. Sci. Technol., 37 (2003), p. 2173

[25] N.A. Thomas, E.D. Chao, K.F. Jarrell Arch. Microbiol., 175 (2001), p. 263

[26] A.J. Wicken, K.W. Knox Biochim. Biophys. Acta, 604 (1980), p. 1

[27] N.A. Amro, L.P. Kotra, K. Wadu-Mesthrige, A. Bulychev, S. Mobashery, G.Y. Liu Langmuir, 16 (2000), p. 2789 